\title{
A Comment on: \\ Storage and the Electricity Forward Premium
}

\author{
Adriaan Bloys van Treslong and Ronald Huisman
}

\begin{tabular}{|l|l|}
\hline \multicolumn{2}{|l|}{ ERIM REPORT SERIES RESEARCH IN MANAGEMENT } \\
\hline ERIM Report Series reference number & ERS-2009-042-F\&A \\
\hline Publication & July 2009 \\
\hline Number of pages & 13 \\
\hline Persistent paper URL & http://hdl.handle.net/1765/16246 \\
\hline Email address corresponding author & rhuisman@ese.eur.nl \\
\hline Address & Erasmus Research Institute of Management (ERIM) \\
& RSM Erasmus University / Erasmus School of Economics \\
& Erasmus Universiteit Rotterdam \\
& P.O.Box 1738 \\
& 3000 DR Rotterdam, The Netherlands \\
& Phone: + 31 10 408 1182 \\
& Fax: + 31 10 408 9640 \\
& Email: info@erim.eur.nl \\
& Internet: $\quad$ www.erim.eur.nl \\
\hline
\end{tabular}

Bibliographic data and classifications of all the ERIM reports are also available on the ERIM website: www.erim.eur.nl 


\section{ERASMUS RESEARCH INSTITUTE OF MANAGEMENT}

\section{REPORT SERIES}

\section{RESEARCH IN MANAGEMENT}

\begin{tabular}{|l|l|}
\hline ABSTRACT AND KEYWORDS \\
\hline Abstract & $\begin{array}{l}\text { This paper examines the robustness of the results found by Douglas and Popova (2008). They } \\
\text { examine the electricity forward premium in relation to gas storage inventories and find that, } \\
\text { although electricity is not directly storable, electricity forward premiums are lower when gas } \\
\text { storage inventories are higher, especially on days with high temperatures. Douglas and Popova } \\
\text { (2008) derive their results from a forward premium model that is an extension of the } \\
\text { Bessembinder and Lemmon (2002) model. We examine the robustness of their results, by } \\
\text { examining whether the gas storage inventory results hold under a different specification of the } \\
\text { forward risk premium. Our result support the results found by Douglas and Popova (2008) and } \\
\text { show that their results are not influenced by the specification of the forward premium model. }\end{array}$ \\
\hline Free Keywords & \begin{tabular}{l} 
forward premium, electricity \\
\hline Availability
\end{tabular} \\
$\begin{array}{ll}\text { The ERIM Report Series is distributed through the following platforms: } \\
\text { Academic Repository at Erasmus University (DEAR), DEAR ERIM Series Portal } \\
\text { Social Science Research Network (SSRN), SSRN ERIM Series Webpage } \\
\text { Research Papers in Economics (REPEC), REPEC ERIM Series Webpage }\end{array}$ \\
\hline Classifications & $\begin{array}{l}\text { The electronic versions of the papers in the ERIM report Series contain bibliographic metadata } \\
\text { by the following classification systems: } \\
\text { Library of Congress Classification, (LCC) LCC Webpage } \\
\text { Journal of Economic Literature, (JEL), JEL Webpage } \\
\text { ACM Computing Classification System CCS Webpage } \\
\text { Inspec Classification scheme (ICS), ICS Webpage }\end{array}$ \\
\hline
\end{tabular}




\title{
A Comment on: Storage and the Electricity Forward Premium
}

\author{
Adriaan Bloys van Treslong ${ }^{a}$ Ronald Huisman ${ }^{\mathrm{a}, \mathrm{b}, *}$ \\ ${ }^{a}$ Erasmus School of Economics, Erasmus University Rotterdam \\ ${ }^{\mathrm{b}}$ FinEdge International Group
}

\begin{abstract}
This paper examines the robustness of the results found by Douglas and Popova (2008). They examine the electricity forward premium in relation to gas storage inventories and find that, although electricity is not directly storable, electricity forward premiums are lower when gas storage inventories are higher, especially on days with high temperatures. Douglas and Popova (2008) derive their results from a forward premium model that is an extension of the Bessembinder and Lemmon (2002) model. We examine the robustness of their results, by examining whether the gas storage inventory results hold under a different specification of the forward risk premium. Our result support the results found by Douglas and Popova (2008) and show that their results are not influenced by the specification of the forward premium model.
\end{abstract}

\footnotetext{
* Corresponding author. Address: Erasmus School of Economics, Erasmus University Rotterdam, P.O. Box 1738, 3000 DR, Rotterdam. Tel: +31 104081334.

Email addresses: adriaanbloys@hotmail.com (Adriaan Bloys van Treslong), rhuisman@ese. eur.nl (Ronald Huisman).

1 The authors would like to thank Stratford Douglas and Julia Popova for providing their data.
} 


\section{Introduction}

The price of a forward contract concerning the delivery of a commodity in a future time period highly depends on the storability of the commodity and the extent in which storage capacity is accessible to market participants. Among many others, Fama and French (1987) describe how traders valuate a forward contract in case of storability of the underlying commodity (theory of storage) or non or limited storability of the underlying good (expectations theory). For storable commodities, the forward prices are based on the fact that a trader who just sold a forward contract can make his position free of risk by purchasing the commodity at the moment of the sale and keep it in his inventory until delivery. In this case, the expected future value of the good is not an issue and the forward price reflects interest rates, storage costs, and convenience yields. A trader who sold a forward on a commodity for which storability is either too costly, or not accessible to every trader, or limited due to storage capacity constraints, or even impossible, cannot make his position free of risk. In such case, the value of a forward equals the expected spot price at the moment of delivery plus some risk premium. Fama and French (1987) argue that the theory of storage and the expectations theory are not mutually exclusive as many commodity are not perfectly storable and convenience yields reflect some kind of expectation anyway. This paper concentrates on the forward price of electricity. Direct electricity storage is too expensive and therefore too inefficient to be useful for traders in electricity derivative contracts. According to the expectations theory, electricity forward prices equal the expected spot price of electricity during the delivery period and an electricity forward premium. Although electricity is not directly storable, power plants may store electricity 
indirectly by storing the underlying fuels and having flexibility in production. This is what Douglas and Popova (2008) argue and they examine the influence of gas storage inventory levels on the electricity forward premium. To do so, they apply a model for the electricity forward premium that is is based on the forward premium model proposed by Bessembinder and Lemmon (2002) and extended with gas storage and temperature variables. Douglas and Popova (2008) find empirical evidence that gas storage inventories influence the electricity forward premium such that electricity forward premiums are lower in times when gas storage inventories are high, especially on days with high temperatures.

The results found by Douglas and Popova (2008) are important. They extend the current knowledge on valuing electricity derivatives prices and show that increased indirect (fuel) storability leads to increased production flexibility which then leads to less electricity price uncertainty and risk a lower electricity forward prices. Given the importance of this result, it is worthwhile to know how their result depends specific choice to use the Bessembinder and Lemmon (2002) model as a basis for the forward premium. An alternative specification would be to use the forward basis as a model framework, as suggested by Fama and French (1987). Therefore, we redo the analysis of Douglas and Popova (2008), with the same data, with the forward basis as an alternative specification for the electricity forward premium. Our results show a high level of consistency with the results of Douglas and Popova (2008) and we therefore conclude that their results are robust to the specification of the forward premium. 


\section{The Douglas and Popova (2008) model}

Douglas and Popova (2008) propose the following model for the electricity forward premium.

$$
\begin{aligned}
\text { Premium }_{t}= & \beta_{0}+\beta_{1} \operatorname{Var}_{t-1}(S)+\beta_{2} \text { Skew }_{t-1}(S)+ \\
& \beta_{3} G S_{t-1}+\beta_{4 a} C D H_{t}+\beta_{4 b} C D H_{t}^{2}+\beta_{5 a} H D H_{t}+\beta_{5 b} H D H_{t}^{2}+ \\
& \beta_{6} G S_{t-1} C D H_{t}+\beta_{7} G S_{t-1} H D H_{t}+\epsilon_{t}
\end{aligned}
$$

The first row of equation 1 is based on Bessembinder and Lemmon (2002) who derive the equilibrium electricity forward price in a wholesale spot market where risk-averse generation and distribution firms act. In their model, the forward price depends on the variance $\operatorname{Var}_{t-1} S$ and the skewness $S k e w_{t-1}(S)$ of electricity spot prices. Bessembinder and Lemmon (2002) discuss that potential price spikes create positive skewness in the perceived distribution of spot prices. The higher the uncertainty due to spikes, the more skewed the perceived distribution is. The higher uncertainty creates a demand for forward contracts and therefore the forward premium is positively dependent on the skewness of prices; hence $\beta_{2}$ is positive. The relation between variance and the forward premium is negative. When the retail price of electricity exceeds the expected spot price, distributors make a profit and a higher variance of spot prices increases expected profits as the correlation between electricity sales and spot prices. When retail prices are below the expected spot prices, then 
a higher variance of spot prices yields a lower downside risk for distributors. In both cases, a higher variance of spot prices reduce the demand for forward contracts from distributors. Hence, the variance of spot prices influence negatively the forward premium and $\beta_{1}$ is negative.

The second and third row in equation 1 is the extension of the Bessembinder and Lemmon (2002) forward premium model as proposed by Douglas and Popova (2008). The temperature factors cooling degree hours $C D H_{t}$ and heating degree hours $H D H_{t}$ have been added because of their major influence on the demand for electricity and gas ${ }^{2}$. High temperatures (high $C D H_{t}$ ) strongly increase the use of air conditioning and thus the demand for electricity. Low temperatures (high $H D H_{t}$ ) affect the heating market and hereby the demand for gas. The quadratic terms allow for nonlinear effects caused by the convexity of the supply curve and can reflect changing marginal effects. The variable $G S_{t-1}$ measures the level of gas storage inventories at time $t-1$. The crossterms $G S_{t-1} C D H_{t}$ and $G S_{t-1} H D H_{t}$ allow for differences in the influence of gas inventory levels on the forward premium for days with high and low temperatures respectively. The parameters in the model is applied to day-ahead (forward) prices in the American PJM market for each of the 24 hours in the delivery days between 2001 and $2004^{3}$.

The results are as follows. The signs for $\beta_{1}$ are negative and significant for most hours and the signs for the $\beta_{2}$ estimates are generally positive, consistent with Bessembinder and Lemmon (2002). Estimates for $\beta_{4 a}$ and $\beta_{4 b}\left(C D H_{t}\right)$ are significant and such high temperatures increase the forward risk premiums due to

$\overline{2}^{2} C D H_{t}=\max \left\{0, T_{t}-65\right\}$ and $H D H_{t}=\max \left\{0,65-T_{t}\right\}$ where $T_{t}$ is the average temperature in day $t$ in degrees Fahrenheit.

3 We refer to Douglas and Popova (2008) for the details about the data 
increased electricity demand from air-conditioning usage. The effect of lower temperatures $\left(H D H_{t}\right)$, reflected by the estimates for $\beta_{5 a}$ and $\beta_{5 b}$, on the forward risk premiums is much weaker than for high temperatures as in addition to electricity also gas, oil, and, wood are used for heating. The major finding of Douglas and Popova (2008) is that estimates for $\beta_{6}$, the coefficient for the cross term $C D H_{t} G S_{t-1}$, are significantly negative indicating that higher gas inventory levels on hot days significantly reduce the forward risk premium. The effect of the cross term for cold days, $H D H_{t} G S_{t-1}$, on the forward premium is negative but again weaker than for warm days. Douglas and Popova (2008) therefore conclude that high gas storage inventories significantly reduce the electricity forward risk premiums, especially on days with high temperatures. Although electricity is not storable, Douglas and Popova (2008) find evidence for indirect storability effects in the electricity forward risk premium.

\section{An alternative specification}

The estimates on the gas inventories variables in equation 1 depend on the specification of the forward premium. In fact, Douglas and Popova (2008) extend the model by Bessembinder and Lemmon (2002) which is listed in the first row of equation 1. An alternative to the Bessembinder and Lemmon (2002) specification is to use the forward basis. Fama and French (1987) show that the basis, being the difference between the forward price and the current spot price, contains information about the risk premium and the expected change between the current spot price and the spot price in the delivery period. Fama and French (1987) formulate two regression equations and estimate the parameters for various (non-energy) commodities. Rewritten in line with the 
Douglas and Popova (2008) model, the regression equations are as follows.

$$
\begin{array}{r}
F_{t}-S_{t}=\alpha_{1}+\beta_{1}\left(F_{t}-S_{t-1}\right)+e_{t} \\
S_{t}-S_{t-1}=\alpha_{2}+\beta_{2}\left(F_{t}-S_{t-1}\right)+e_{t}
\end{array}
$$

In the equations, $F_{t}$ is the day-ahead forward price for delivering $1 \mathrm{MW}$ in a specific hour on day $t$ and $S_{t}$ be the spot price for the delivery hour. Note that the quote for $F_{t}$ is observed one day before delivery on $t-1$. Equation 2 shows that a fraction of $\beta_{1}$ of the forward basis observed at time $t-1, F_{t}-S_{t-1}$, relates to the forward premium and that a fraction of $\beta_{2}$ of the basis relates to the change in the spot price between $t-1$ and $t$. Fama and French (1987) discuss two theories that explain to what extend the forward basis reflects risk premium and expected spot price changes. The first is the theory of storage and applies to (perfectly) storable assets. The forward reflects the current spot price, interest rates, storage costs, and a convenience yield. Apart from these, the forward price does not embed any information about the future expected spot price. Hence, $\beta_{2}$ should be zero. The second theory is the expectations theory and applies to non-storable (such as electricity) or for which storability is not perfect (such as natural gas). It states that the forward price consists of the market expected future spot price and a risk premium. In this case, both $\beta_{1}$ and $\beta_{2}$ would lie somewhere between 0 and 1 .

The first line in equation 1 is a specification of the forward premium which is an alternative to the Bessembinder and Lemmon (2002) model that is used in Douglas and Popova (2008). To test whether the outcomes of Douglas and 
Popova (2008) are robust with respect to the specification of the forward premium, we replace the Bessembinder and Lemmon (2002) specification with the one in the first line of equation 1 . The alternative model then becomes:

$$
\begin{aligned}
\text { Premium }_{t}= & \beta_{0}+\beta_{1}\left(F_{t}-S_{t-1}\right)+ \\
& \beta_{2} G S_{t-1}+\beta_{3 a} C D H_{t}+\beta_{3 b} C D H_{t}^{2}+\beta_{4 a} H D H_{t}+\beta_{4 b} H D H_{t}^{2}+ \\
& \beta_{5} G S_{t-1} C D H_{t}+\beta_{6} G S_{t-1} H D H_{t}+\epsilon_{t}
\end{aligned}
$$

As electricity is not (directly) storable, we expect the estimates for $\beta_{1}$ to be between 0 and 1 .

\section{Data}

We use the same data as Douglas and Popova (2008). The sample consists of hourly day-ahead and spot price observations between January 1, 2001 until December 31, 2004. The real time and forward electricity prices have been obtained from the Pennsylvania-New Jersey-Maryland (PJM) Interconnection and correspond to the whole regional transmission organization (RTO). The gas storage input data originate from the weekly (and prior monthly) reports of the Energy Information Administration (EIA) and relate to the East (Consumption) Region. Finally, the temperature data are from the Global Summary of the Day (GSOD) database of the National Climatic Data Cen- 
ter (NCDC) and consecutively compiled by ZedX, Inc, Atmospheric Sciences Division. The composition of the input variables gas storage, cooling degree hours, heating degree hours, the premium and the quadratic and interaction terms is identical to Douglas and Popova (2008).

\section{$5 \quad$ Results}

Following Douglas and Popova (2008), we estimate the parameters in 3 separately for each delivery hour using ordinary least squares. The tables 1 and 2 list the parameter estimates and Newey-West standard errors, which are robust to heteroskedasticity and autocorrelation.

Before comparing our results with Douglas and Popova (2008), we focus on the parameter associated with the basis, $\beta_{1}$. The tables show that the estimates are significantly different from zero for most hours, except for the delivery hours $2 \mathrm{pm}$ through $6 \mathrm{pm}$. The estimates vary between -0.08 for $6 \mathrm{pm}$ and 0.23 for midnight, 9 am, and 11pm. The forward basis has explanatory power for the risk premium, with a relatively low $\beta_{1}$ which is in line with the expectations formulated by Fama and French (1987). For storable assets, the estimate for $\beta_{1}$ is expected to be close to one, whereas for not perfectly storable assets the estimate for $\beta_{1}$ is smaller than one as the forward basis reflects information about the to be realised risk premium and expected future price changes as formulates in equation 2 . 


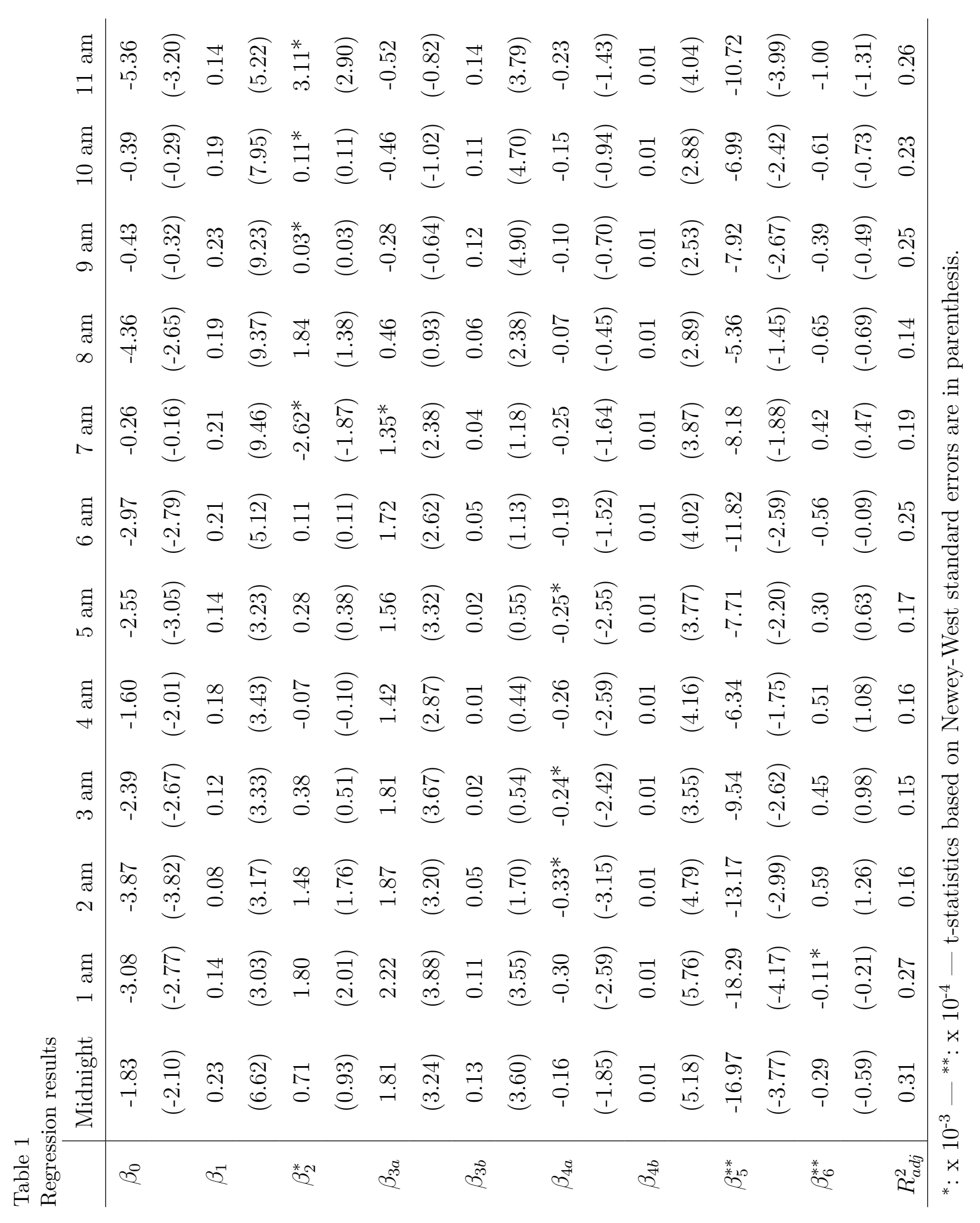




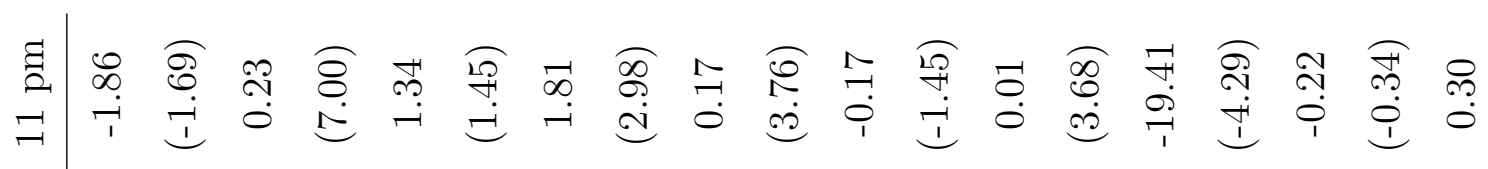

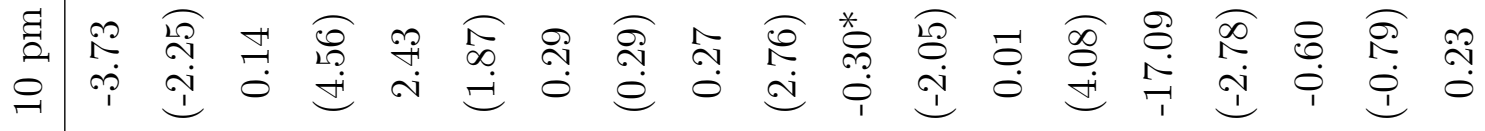

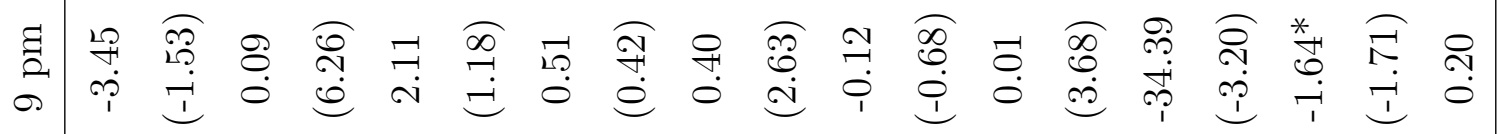

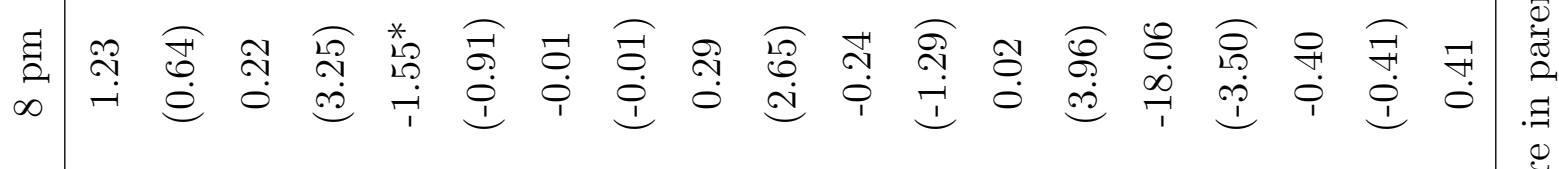

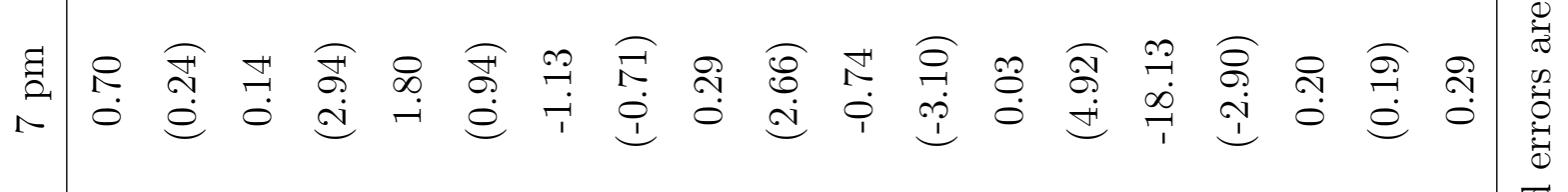

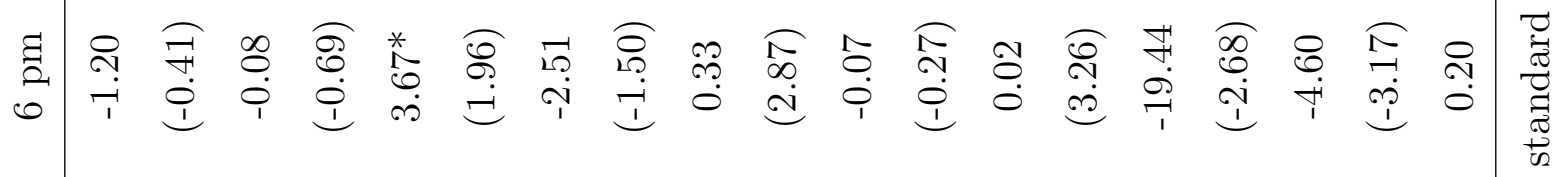

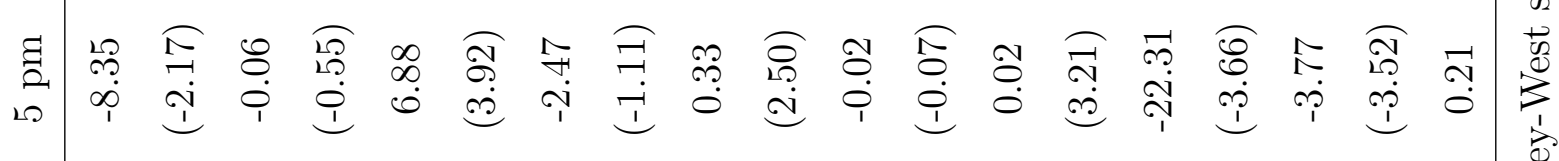

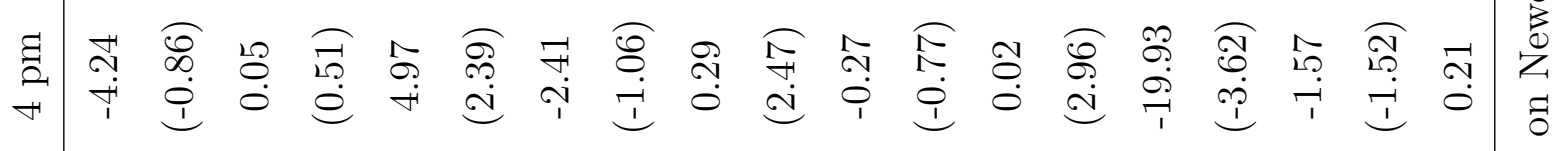

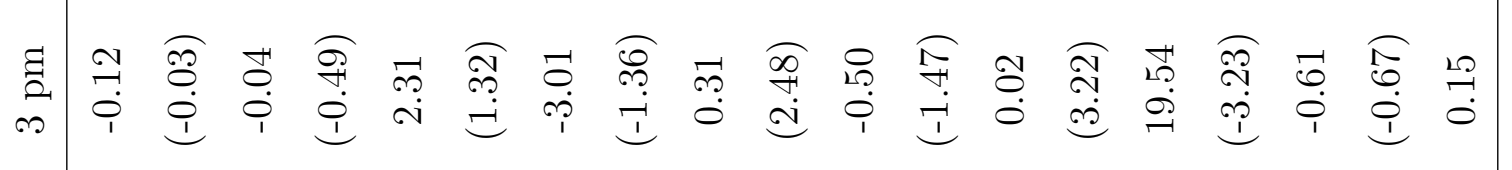

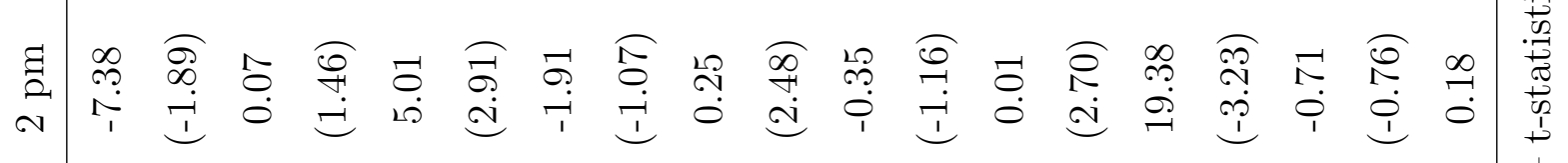

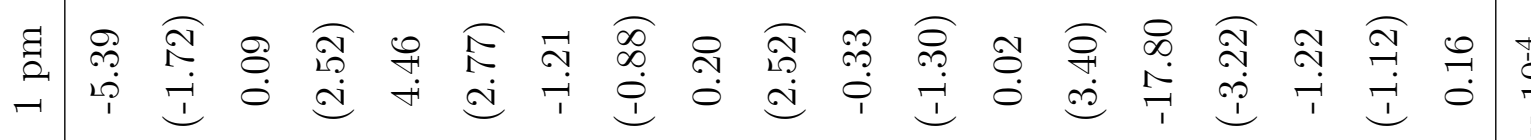

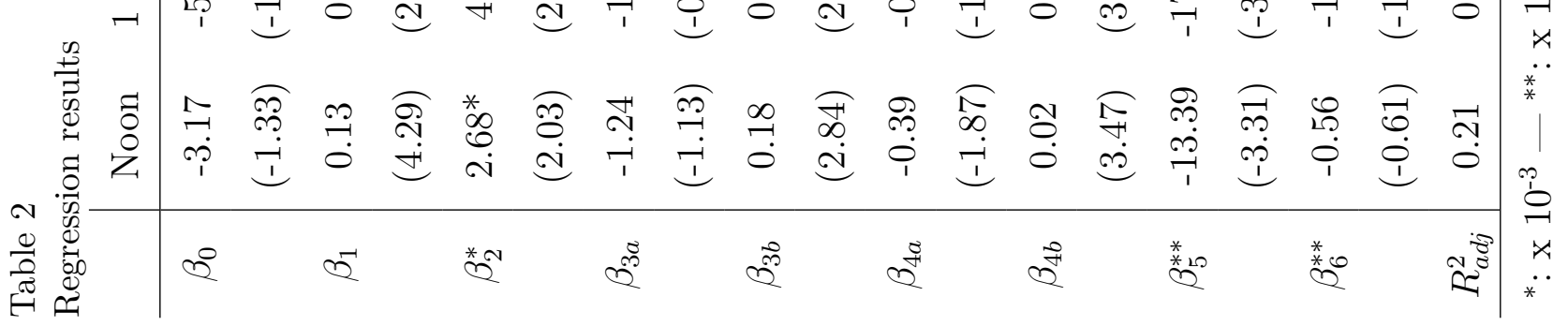


The main issue of this paper is to test the robustness of the outcomes of Douglas and Popova (2008) for the choice of premium model used. Let's first analyse the fit of both models. The average $R_{a d j}^{2}$ over the 24 hours reported in Douglas and Popova (2008) is 0.37. The average $R_{a d j}^{2}$ reported in tables 1 and 2 is 0.22 . The Douglas and Popova (2008) model explains on average $15 \%$ more of the variation in the risk premium than our model. The second comparison is whether the outcomes as reported in tables 1 and 2 for the estimates $\beta_{2}$ through $\beta_{6}$ differ substantially from Douglas and Popova (2008). In the tables, a value indicated with $*$ reflects a substantial difference between both studies which is defined as either an estimate which was significant in Douglas and Popova (2008) and not here and vice versa, or a significant estimate for which the sign differs between both studies. It is apparent that only a few outcomes differ substantially between both studies. For that reason, it seems that the outcomes from Douglas and Popova (2008) are in line with the model presented in this paper and that the choice of risk premium model does not cause many outcomes to differ. Our estimates support the findings of Douglas and Popova (2008) that increased gas storage inventories significantly reduce the forward premium and that the impact of gas inventories is weaker when heating demand is high. The latter can be observed from the estimates for $\beta_{5}$ which are negative and highly significant in comparison with the estimates for $\beta_{6}$ which are negative but hardly significant.

\section{Concluding remarks}

This paper examines the robustness of the results found by Douglas and Popova (2008). They examine the electricity forward premium in relation 
to gas storage inventories and find that, although electricity is not directly storable, electricity forward premiums are lower when gas storage inventories are higher, especially on days with high temperatures. Douglas and Popova (2008) derive their results from a forward premium model that is an extension of the Bessembinder and Lemmon (2002) model. We examine the robustness of their results, by examining whether the gas storage inventory results hold under a different specification of the forward risk premium. Instead of the Douglas and Popova (2008) specification, we use the forward basis as an explanatory variable for the forward premium as suggested by Fama and French (1987). Using the same data set, we redo the analysis of Douglas and Popova (2008) based on the alternative specification of the forward premium. Our results support the results found by Douglas and Popova (2008) and show that their results are not influenced by the specification of the forward premium model. As Douglas and Popova (2008), we therefore conclude that high gas storage inventories significantly reduce the electricity forward risk premiums, especially on days with high temperatures. Although electricity is not storable, indirect storability effects influence the electricity forward risk premium.

\section{References}

Bessembinder, H., Lemmon, M., 2002. Equilibrium pricing and optimal hedging in electricity forward markets. Journal of Finance 57(3), 1347-1382.

Douglas, S., Popova, J., 2008. Storage and the electricity forward premium. Energy Economics 30 (4), 1712-1727.

Fama, E., French, K., 1987. Commodity futures prices: Some evidence on forecast power, premiums, and the theory of storage. Journal of Business $60(1), 55-73$. 


\section{Publications in the Report Series Research* in Management}

\section{ERIM Research Program: "Finance and Accounting"}

\section{9}

Sorting out Downside Beta

Thierry Post, Pim van Vliet, and Simon Lansdorp

ERS-2009-006-F\&A

http://hdl.handle.net/1765/14843

A Comment on: Storage and the Electricity Forward Premium Adriaan Bloys van Treslong and Ronald Huisman ERS-2009-042-F\&A

http://hdl.handle.net/1765/16246

A complete overview of the ERIM Report Series Research in Management: https://ep.eur.nl/handle/1765/1

ERIM Research Programs:

LIS Business Processes, Logistics and Information Systems

ORG Organizing for Performance

MKT Marketing

F\&A Finance and Accounting

STR Strategy and Entrepreneurship 